\title{
Teaching Materials and Islamic Value Based Need Analysis the Teachig Material at Anthropology Subject:The Case on Universitas Islam Negeri Imam Bonjol Padang
}

\author{
Lisna Sandora ${ }^{1}$, Firman ${ }^{2}$, Fitri Eriyanti ${ }^{3}$ \\ ${ }^{1,2,3}$ Education Science Department, Universitas Negeri Padang, Padang, Indonesia \\ *lisnasandora@yahoo.co.id
}

\begin{abstract}
Anthropology provides understanding, experience, mental attitude and cultural behavior and prepare students to qualified in multicultural society and be able to apply both individually and in groups within the campus, community and nation. This paper aomed atto analyzing the needs on teaching materials at Anthropology class which is based on Islamic values. It used is descriptive qualitative, with a descriptive approach. The teaching materials development is based on Islamic Values beside being trated with blended learningand the students must pay attention to the learning otcome both practical and theories of teaching materials which is based on Islamic values. A wide range of material which integrated with Islamic values enable students in attitudes and skills and knowledge, and presents learning activities as formulated in scientific approach (Observing, Asking, Trying, Analyzing, and Concluding). The analysis is to make Anthrophopology teaching materials underpined by Islamic Valuesthe teaching valid, interesting practical and effective blended learning in higher education.
\end{abstract}

Keywords: Need Analysis; Learning Materials; Athropology

\section{Introduction}

Anthropology as a subject that studies the physic, culture, personality, society, community dynamics and diverse cultures connected with nature human being. It is the lecture task to provide understanding, experience, mental attitude and cultural behavior and help the students become a qualified in multicultural society beside being able to use them in a campus. As one of the one of majorbsubject in the departement, it provide the students with the basic understandings on anthropology, need to be effectively carry out, the intended anthropology learning process help yhe teacher candidates to have expertise, skills and develop selfawareness wich is based on the local culture and professional in the field of Pancasila and citizenship education $[1,2]$.

Teaching material is one of the main factors for the learning effectiveness especially for tertiary level. The limitation ot lack rrlated wih teaching materials can affect the learning or lecture quality . a study showed that teaching materials do not fulfill the needs. To provide meaningful learning experience, a lecturer must have apropriate teaching materials that that based on the students real need. Teaching materials can assist lecturers in improving the 
learning process to be more effective and efficient [3]. some efforts to overcome the problems related to the quality of the learning process in higher education in general and the quality of anthropological learning in particular must be sustained and improved. In light, it is necessary to carry out sone various update on the lecture process, especially for anthropology courses, as an effort to improve the process quality and its output, through the development of relevant learning teaching materials. In the reality that happens to students, that the learning process used by teachers is still monotonous, is only fixed in one direction so that it causes learning (bored, sleepy, emotional, stiff, memorizing) and learning material is not presented completely and comprehensively only presents Semester Learning Design ( RPS) and Weekly Learning Design (RPM), and only the summary of teaching material made in the form of power point slides and the availability of books in the library are still incomplete in explaining the concept of cultural anthropology.

On the otherside the learning process is influenced by two factors, namely internal and external factors. Internal factors related with the elements from within soul, mental, attitude, and student motivation that are not optimal and are not even well guided, while external factors are external elements: learning tool (RPS and RPM, textbooks) as the references for students in the learning process in the classroom and outside the classroom are not available in full. Both of these problems need responded for a solution to make the learning process meaningful beside can improve the quality of higher quality lectures. Monotonous learning eliminated because it entails a learning process (bored, sleepy, emotional, stiff, memorizing) and learning material is not presented in a large context and comprehensively in describing cultural anthropological concepts. For this reason there is a need have an update on the lecture process, especially in cultural anthropology courses in order to improve the quality of the process and its output [4].

Efforts in various ways have been made in term of improving the Indonesian educational quality Improvement and development of the quality of teaching materials is one of the steps to gain the improvement. The development of good teaching materials is needed, used as a source of learning or a source of information in the learning process [5]. Lecturers as the educators participate in developing anthropological teaching materials which based on Islamic values. According to Cholis [5] The factor that can influence students in learning is the background knowledge they have before they learn a concept or new knowledge. Acording to constructivism, lecturers need to provide opportunities for students to actively build their own knowledge by taking into account the initial abilities they have. In order to make teaching materials that are prepared based on the ability of students will be very helpful in learning activities undertaken. Anthropological teaching materials based on Islamic values can be used as supporting books in learning in addition to textbooks available on the market. To make it easier to deliver disituation materials that are currently difficult it is necessary to design an internet-based learning model is one of the most popular manifestations of e-learning, which offers various benefits such as more flexible learning opportunities without being bound by space and time, making it easier for people to access education, enrich learning material, enlivening the learning process, making the learning process more open, increasing the effectiveness of learning, and supporting students to learn independently [4].

An Anthropology class require teaching materials in accordance with the curriculum needs and student characteristics. Based on the results of preliminary research that has been carried out, the teaching material of Anthropology courses at the Imam Bonjol State Islamic University of Padang, the lesson or teaching materials has met the need, teaching materials need to be developed by considering several components. The intended components include the accuracy of the content, the accuracy of the scope of the material, the digestibility of the 
teaching material, the use of language, illustrations, appearance or packaging, and the completeness of the teaching material components.

This research used aqualitative research. Qualitative research is a research method used to examine natural object conditions [6]. In accordance with the type of research used, the research approach chosen by the author is a descriptive approach. Descriptive approach is used based on the consideration that the problems to be investigated are ongoing at the present time which aims to analyze the phenomena that occur in the field. In accordance with the approach used, the presence of the writer in the field or research location is needed. The reason is that the writer acts as a key instrument that tries to adjust to the situation and conditions in the field, and seeks to create good relationships with informants related to research.

The data source is devided into primary data sources and secondary data sources. Primary data sources were obtained from informants who has the capability to tell the information in detail and clear related with the this study. The informant is a lecturer who teaches Anthropology at UIN Imam Bonjol Padang. Secondary data sources was obtained through observation studies to noticet he implementation of learning and documentation which includes mapping the preparation of the syllabus, documents include teaching materials, photos of learning activities, and other supporting data. The researcher used hree techniques to obtain data : interview, observation and documentation techniques. Analysis of the data in this paper refers to the qualitative analysis stated by Miles and Huberman. The stages data are: data reduction, data display, conclusion and verifying [7].

\section{Methodology}

The research method used is descriptive analysis with a library research approach

\section{Result and Discussion}

\section{a. Analysis of Teaching Materials}

The results of the analysis of syllabus and RPS mapping used by lecturers in lectures generally proved that the two main tool used by the lecturers are power points and books. The researcher conducted an analysis of the material mapping. It also proved that the subject matter is in accordance with the RPS mapping. But, the various learning activities presented have not been linked to Islamic values. The teaching materials used are handout of RPS and Syllabus but there were none of themintegrated with Islamic value.

Teaching materials used by lecturers supporting anthropology courses in the form of modules, and sometimes modules are not updated, every year that is taught to students is just the same, lacking in the creativity of lecturers in developing innovative teaching materials in courses in each semester. At present there is still little, even said not much teaching material based on bleanded learning that is used by teachers in learning. Only slite powerpoints from each topic given to students.

b. The use of teaching materials anthropology courses 
Based on the results of interviews conducted by the author to lecturers who teach Anthropology courses it can be seen that in general lecturers using teaching materials themselves are added to materials from other available sources published by anthropology experts. To improve students' understanding of the concept of lecturers using other supporting books such as the Models compiled by the lecturers themselves and ISBN. This is in line with the statement of Musanna [8] that to obtain maximum learning outcomes, it is necessary to have learning resources that are integrated with Islamic values in accordance with the direction taken by the student. In general, the supporting books used by lecturers still contain a few activities that shape or enhance aspects of attitude and skills. The book tends to develop aspects of knowledge in the form of practice questions only. This is not in line with Warianto [9] that in order to equip students to become human with character, it is necessary to have a positive habituation through internalization of character values in the learning activities carried out. Based on this phenomenon shows that the mastery of students' concepts of Natural Resources that are around is still limited.

\section{c. Constraints and Efforts}

The lecturers face some difficulties in associating the course material with Islamic values if only refer to the activities contained in the guidebook. Trainings have not been widely obtained, so lecturers teach in accordance with the wishes of lecturers supporting each course. Supporting learning, the elements of Anthropology lectures from the planning process to evaluation has been highlighted in the learning tools in the form of: (1) Learning Plan (RP), (2) Modules, (3) Student Worksheets, (4) Power Points.

\section{d. The Draft Development}

In developing Anthropology teaching materials based on Islamic values must pay a concern on: (1) Awide range of material that is integrated with Islamic values, (2)Various learning activities that can activate students in aspects of attitudes, skills, and knowledge, (3) presents learning activities that are tailored to the steps of the scientific approach (Observing, Asking, Trying, Analyzing, and Concluding) so as to train students to think scientifically. The intended Teaching materials consists of two books, namely students' books and lecturer books. Student manuals are used by students during learning activities, and lecturer books are used by lecturers as guidelines for the implementation of learning activities to be carried out. The systematic compilation of student books is that each learning consists of: (a) a map of learning concepts, (b) learning objectives, (c) subject matter, (d) student activities, and (e) test questions. Whereas the systematic compilation of the lecturer handbook is complemented by: (a) syllabus and RPS mapping, (b) learning steps, (c) observation sheets, (d) assessment criteria, (e) test questions collection sheets, (f) answer key, (g) bibliography, and (h) glossary.

Teaching materials development planned Anthropology teaching materials which is based on Islamic values accompanied by learning blended learning in the current situation is very necessary online teaching materials that can be used by lecturers in delivering learning materials to students. The New Normal Era requires lecturers to be technology literate so that learning can be done online, learning provided along with teaching materials based on blended learning enables learning to be effective and students become more enthusiastic in the learning process. According to Abdul Majid [10] Teaching materials are all forms of material used to assist teachers / instructors in carrying out learning activities in class. The material in question can be either written material or unwritten teaching material. Components of instructional materials or instructional materials generally consist of knowledge, skills and attitudes that students must learn in order to achieve predetermined competency goals [11]. 
Teaching material aims at making the students understand the knowledge and skills learned, if necessary prepared multimedia teaching materials. The provision of teaching materials that are very complete and easy to obtain and the use of teaching aids that are equipped with interesting drawings, motion, sound, simulations and are guided by the instructor in a virtual manner and can be repeated (replays) will make students feel at home and easily digest knowledge with well. Like the newspapers now who like current or present news with pictures and graphics to help readers understanding the contents. These three ways of learning are perfect when they are colored with information technology capabilities, where learners can hear, read, and also demonstrate, even in cyberspace, but are good for shaping the knowledge of student actors. The recommendation from Unesco to utilize the internet through the available web or the lecturer's personal web to place teaching materials is an advance in technology and information.

A learning model that can be applied through the use of technology-based media is the blended learning model. According to Driscol [12] Blended learning is learning that combines or combines various web-based technologies, to achieve educational goals. Thorne (2013) defines blended learning as a mixture of elearning and multimedia technologies, such as video streaming, virtual classes, online text animation combined with traditional forms of classroom training. Blended learning more simply as learning that combines online learning with face-toface (face-to-face learning).

Anthropology as a study of humans and their relation with their culture. This science has been rapidly developed by world anthropologist. Anthropology oand religion cannot be separated from culture, because anthropology is a religious institution in society. Culture must be clear because there are many contadictory definitions $t$ are found. Many anthropologists define culture from a variety of different perspectives. These different points of view even give birth to differences in flow in cultural anthropology. Simply put, the vast differences in the definition of culture can be grouped into seven. Culture as a system of knowledge, ideas, recipes, behavior codes that are abstract, or patterns for those contained in the system Students can explain the similarities and differences in religion and culture, the knowledge of individuals as members of society.

\section{Conclusion}

The development of teaching Antopology teaching materials based on Islamic Values for students regard results of the study of phenomena in the field and theories about the development of teaching materials based on Islamic values. Some very important note can drawn are: First, it has a wide range of material integrated with Islamic values. Second, activate students from both aspects of attitude, skills and knowledge. The third, presents learning activities that are imply scientific approach (Observing, Asking, Trying, Analyzing, and Concluding). Finally the teaching materials must be arranged along with valid, interesting practical, and effective blended learning learning used in a tertiary institutions. 


\section{References}

[1] Sakban A, Muttaqin Z. Pengembangan Modul Pembelajaran Antropologi Budaya Dengan Pendekatan Deep Dialogue and Critical Thinking Untuk Mahasiswa Pendidikan Pancasila dan Kewarganegaraan 2017.

[2] Huda MD. Pendekatan Antropologis dalam Studi Islam. Didakt Religia 2016;4:139162-162. https://doi.org/10.30762/didaktika.v4.i2.p139-162.2016.

[3] Ulfah A, Jumaiyah J. PENGEMBANGAN BAHAN AJAR MATA KULIAH BAHASA INDONESIA DI PERGURUAN TINGGI KABUPATEN LAMONGAN. J Inov Pendidik 2018;2.

[4] Munfa'ati K. Integrasi nilai Islam Moderat dan Nasionalisme pada pendidikan karakter di Madrasah Ibtidaiyah Berbasis Pesantren: studi multi kasus di MI Miftahul Ulum Driyorejo Gresik dan MI Bahrul Ulum Sahlaniyah Krian Sidoarjo. masters. UIN SUNAN AMPEL SURABAYA, 2018.

[5] Sulistyani N, Sa'dijah C. Analisis Kebutuhan Pengembangan Bahan Ajar Berbasis Kearifan Lokal Kota Batu. Semin. Nas. Teknol. Pembelajaran Dan Pendidik. Dasar 2017, 2017, p. 836-44.

[6] Sugiyono. Metode Penelitian Kuantitatif, Kualitatif, dan R\&D. Bandung: CV. Alfabeta; 2019.

[7] Miles MB, Huberman AM. Analisis data kualitatif: buku sumber tentang metodemetode baru. 1992.

[8] Al Musanna. MODEL KURIKULUM KEARIFAN LOKAL DALAM PENDIDIKAN GURU: Studi Desain dan Implementasi Kurikulum Budaya dan Literatur Gayo Jurusan Tarbiyah Sekolah Tinggi Agama Islam Gajah Putih Takengon. phd. UNIVERSITAS PENDIDIKAN INDONESIA, 2014.

[9] Warianto W. Keterampilan Proses Sains. Jakarta: Kencana Prenada Media Group; 2011.

[10] Majid A. Perencanaan pembelajaran: mengembangkan standar kompetensi guru. Bandung: Remaja Rosdakarya; 2006.

[11] Hamdani H. Strategi Belajar Mengajar. Bandung: Pustaka Setia; 2011.

[12] Driscoll M. Blended Learning: Let's Get Beyond the Hype n.d. 